JOURNAL OF SECURITY AND SUSTAINABILITY ISSUES

ISSN 2029-7017 print/ISSN 2029-7025 online

2019 September Volume 9 Number 1

http://doi.org/10.9770/jssi.2019.9.1(19)

Scopus

\title{
IMPACT OF MACROECONOMIC INDICATORS ON DEVELOPMENT PATTERNS: CASE OF TOURISM INDUSTRY IN ASEAN REGION
}

\author{
Muhammad Haseeb ${ }^{1}$, Gholamreza Zandi ${ }^{2}$, Nizam Mohammad Andrianto ${ }^{3}$, Thitinan Chankoson ${ }^{4 *}$ \\ ${ }^{\prime}$ Taylors Business School (TBS), Taylors University Lakeside Campus, 1 Jalan Taylors Subnag Jaya Malaysia \\ ${ }^{2}$ Universiti Kuala Lumpur Business School, Malaysia \\ ${ }^{3}$ Management Program, Pakuan University, Indonesia \\ ${ }^{4}$ Faculty of Business Administration for Society, Srinakharinwirot University, Bangkok, Thailand \\ E-mails: ${ }^{1} m u h a m m a d . h a s e e b @ t a y l o r s . e d u . m y ;{ }^{2 Z a n d i @ u n i k l . e d u . m y ; ~}$ \\ ${ }_{3}^{3}$ nizam.andrianto@gmail.com ; ${ }^{*}$ tchankoson@gmail.com (corresponding author)
}

Received 11 January 2019; accepted 25 June 2019; published 30 September 2019

\begin{abstract}
The purpose of this research is to examine the impact of macroeconomic indicators on tourism revenue from five states of ASEAN region. To address this objective secondary data is collected over last 18 years from 2001-2017 with annual observations. Macroeconomic indicators include inflation, oil prices, industrial growth, exchange rate stock market index, and gross domestic product over time. Method of the study is based on regression OLS estimation with robust standard errors. Empirical findings indicates that key determinants for the change in tourism revenue in selected countries are exchange rate, stock market index, inflation and industrial growth. However, impact of GDP on tourism revenue is also significant for Malaysia, Indonesia, and Brunei. Study findings can be very much beneficial for present decision-making regarding growth in tourism industry in ASEAN region. Limitations of the study includes less than 20 years of time duration, ignoring the microeconomic indicators of tourism revenue and cross-sectional analysis. Future studies can address these limitations which better understanding and practical implications.
\end{abstract}

Keywords: tourism revenue, inflation, GDP, stock market index, industrial growth, ASEAN.

Reference to this paper should be made as follows: Haseeb, H.; Zandi, G.; Andrianto, N.M.; Chankoson, T. 2019. Impact of macroeconomic indicators on development patterns: case of tourism industry in ASEAN region, Journal of Security and Sustainability Issues 9(1): 257-268. http://doi.org/10.9770/jssi.2019.9.1(19)

JEL Classifications: L83, P24, J53

\section{Introduction and Background of the Study}

For the world trade and prosperity tourism is one of the key driver (World Tourism Organization, 2019; Hossain et al, 2018; Islam et al, 2018; Kabir et al, 2018; Chkalova et al., 2019; Shevyakova et al., 2019). Importantly, over the time ASEAN tourism industry has grown. According to the World travel and tourism council (2017) they mentioned that overall 7.6 trillion US\$ has generated revenue from travel and tourism which is $10.2 \%$ of overall global GDP. In addition, ASEAN countries are providing equal promotion of all their region destination to develop more sustainable. Therefore, tourism and travel considered as one of key contributor for generating revenue. In terms of revenue generation tourism industry has significance impact in the economy for future continuous growth. Therefore, effects of macroeconomic variables are true extent for tourism revenue. Presently, Ordinary least square regression and quantile regression are not yet used to predict the effect of macroeconomic variables on tourism revenue of ASEAN countries. All number of countries in ASEAN community are considered equally intention to identify the relationship of macroeconomic variables. Additionally, the growth of tourism industry is found in all regions who are providing more safety and healthy facilities to tourists (Mahrinasari et al. 2019). 
ASEAN countries association are being held in 1967 in Thailand with initial five countries member. For instance, Malaysia, Singapore, Indonesia, Philippines, Thailand and Malaysia. Thereafter, additional countries join ASEAN community such as Vietnam, Brunei Darussalam, Myanmar, Laos and Cambodia. They caption the motto of "One vision, one identity and one community". These joint communities are tending to generate quality opportunities after collaboration with the basic pillars. These three pillars are named as Economic community, political security community and socio-cultural community. According to ASEAN Tourism Agreement (2015) they reported 13 articles regarding sustainability goals in terms of social progress, culture development, training for enhancing skills, collaboration for living better standards to provide organization cooperation with international region.

\section{Overview of Tourism Industry in ASEAN}

From the context of tourism industry, a strategic plan is developed by ASEAN member for the time period of 2016 to 2025. It is believed that tourism industry in ASEAN member is playing its vital role for the economic growth and financial progress. For this purpose, all member states have consolidated their services in terms of quality of services to the tourists, marketing, human resource development, investment in mega projects, participation from the local community, sustainable development and attracting more tourists in local market. Under this objective for 20025, the factor of promotion and marketing covers the enhancement of ASEAN tourism and statistical framework. To offer diversify products in tourism, activities under the title of complete and ongoing identification of new product development with marketing efforts have been defined. For the attracting tourism investment, plan is developed which coordinates the convergence and investment for the tourism infrastructure. For raising capability and capacity in the field of tourism, mutual recognition is conducted for the professional development. While for the enhancement of facilities, overall agreement between ASEAN countries is developed under the title of "article 2 of ASEAN Tourism Agreement 2002".

Following are the core highlights under the tourism plan of 2025:

- The member states will contribute towards the GDP through more tourism up to 12 to $15 \%$.

- The share of employment in tourism industry could increase from 3 to $7 \%$.

- Spending in terms of per capita by those who are visiting these member states will increase from 877 US dollars to approximately 1500 US dollars.

- The activity of community-based tourism could increase from 43 to more than 300 .

After the review of tourism industry in ASEAN, since 2001 to 2014, total number of tourists from international market has been increased to 105 million in 2014, which are 42 million back in year 2001. This significant increase indicates the fact that huge amount of revenue is coming towards these countries, providing more growth opportunities and financial outcomes. While in depth analysis of this arrival indicates the fact that 12 percent arrival is from Europe, more than 30 percent from Asia, while 46 percent of tourists were coming from Intra ASEAN. In addition, 4 percent are those who belongs to America and 4 percent also from Oceania. In addition, rest of the 4 percent from total tourists are not specified very well. Figure 2 provides a comprehensive view of this trend during 2014 (Secretariat, 2016; Keho, 2017; Khan, 2018; Lari et al, 2017). The forecasting of international arrivals to ASEAN is also presented under the below findings, which covers there region; world, Asia \& pacific, and southeast Asia. It is believed that 2010-2020 3.8 percent tourists are coming from world economy, while specifically 5.7 percent are coming from Asia \& Pacific and 5.8 percent from Southeast Asia (Secretariat, 2015). (Figure 1). 


\begin{tabular}{|l|c|c|c|c|c|c|}
\hline \multirow{2}{*}{ Region } & \multicolumn{2}{|c|}{$\begin{array}{c}\text { Projected Growth } \\
\text { in Arrivals }\end{array}$} & \multicolumn{2}{c|}{ Actual } & \multicolumn{2}{c|}{ Projections } \\
\hline & $\mathbf{2 0 1 0 - 2 0 2 0}$ & $\mathbf{2 0 2 0 - 2 0 3 0}$ & $\mathbf{2 0 1 3}$ & $\mathbf{2 0 2 0}$ & $\mathbf{2 0 2 5}$ & $\mathbf{2 0 3 0}$ \\
\hline World & $3.8 \%$ & $2.9 \%$ & 1,087 & 1,360 & 1,569 & 1,809 \\
\hline Asia and Pacific & $5.7 \%$ & $4.2 \%$ & 248 & 355 & 436 & 535 \\
\hline Southeast Asia & $5.8 \%$ & $4.3 \%$ & $102 *$ & 123 & 152 & 187 \\
\hline
\end{tabular}

Figure 1. Forecasting of international arrivals to ASEAN

Source: Secretariat (2015)

Based on above overview, this study has been conducted for the tourism revenue in ASEAN from the context of macroeconomic indicators. After the detailed review of literature, it is found that earlier studies are missing with the context of ASEAN and majority of focus is towards the Europe and other developed countries having significant tourism market. However, the focus towards ASEAN specifically from the context of macroeconomic determinants and tourism industry is missing. In this context, this study will reasonably be covering the literature gap, both theoretically and practically. The rest of the study is as follows. Next section has provided critical review of the literature for tourism industry and macroeconomic indicators in different regions. Section three explains variables, their operational significance with literature evidence. Section four indicates the methods being applied in the study. Section five shows results and their valuable discussion for the association between variables. Last section gives conclusions, limitations and some future directions.

\section{Related Literature}

In the developed countries, international arrivals of tourist affecting factors has been study extensively. However, according to the tourist arrivals report of 2010-15 shows the five-year tourist arrivals continuous increased trend. In this regard, such studies yet not carried to explore the relationship of macroeconomic indicators and revenue of tourism among ASEAN countries. More importantly, in previous studies seasonal analysis based on each year has been abandoned. Therefore, this study bring more extensive in nature to explore influencing macroeconomic factors.

Various studies argued that arrival of tourism is better explained by income because it shows the detailed earning of tourism sector (Croes \& Vanegas Sr, 2005; Jang, Bai, Hong, \& O’Leary, 2004; Wang, 2009; Wattanakuljarus \& Coxhead, 2008). It is further added that higher income are bigger spender then lower income. According to Jang et al. (2004) who argued that in USA Japanese young educated travelers are more interested to visit comparatively to other developed countries. Algieri (2006) explains key indicators of Russian tourism, for instance gross domestic product (GDP) had found positive significant long run cointegration association. He further explained that intense demand of foreigner travelers are more concern to luxurious and good services which tends to increase in the income level of tourism. In contrary, Dritsakis (2004) used vector error correction approach to determine relationship of macroeconomic factor on Greece industry.

This study concluded that higher income in Great Brittan and Germany are leading due to attractive macroeconomic factors. In another study of Lim, Min, and McAleer (2008) who used ARIX model to express the influence of income change of New Zealand from Japanese arrivals. It is argued that origin country income level is associated from tourist arrival factors. This study is concerning to use industrial production index (IPI) due to lack of monthly data of GDP because in previous there are very few studies who mentioned the importance of industrial production index for tourism demand. In Jeju Island, Singapore, Thailand, and Philippines has correlational demand which is statistically proved through using VEC industrial production (Seo, Park, \& Yu, 2009). Thereafter, another important macroeconomic factor is exchange rate. There is a rich literature of exchange rate that influence tourism demand in past studies. According to the Box and Cox (1964) and Croes and Vanegas $\mathrm{Sr}$ (2005) who used appropriate functional method (linear equation and log linear) to determine the influence of tourism demand through exchange rate fluctuation. They revealed from the result that exchange rate is most vital element for travelers of Venezuelan and Aruba. Similarly, Seo et al. (2009) explains through VEC model that 
exchange rate is influencing factor for raising demand of tourist of Thailand, Philippines and Jeju island. They further added that tourist of South Korean are easing to visit Philippines when real exchange rate is at minimum level. However, exchange rate is noteworthy explanatory variables to influence tourist demand (Algieri, 2006; Hiemstra \& Wong, 2002; Saayman \& Saayman, 2008; Wang, 2009; Hussain et al., 2018). In previous studies, inflation is not much exploring to determine true determinants of tourism revenue. According to (Chen, 2007a) and (Chen, 2007b) who argued that in hotel stock return of china has association with macro and non-macro factors. Regarding stock index and crude oil has proposed to influence the tourist demand in ASEAN countries because besides higher income group there are lower- and middle-income group are also visiting tourist destination. Therefore, higher crude oil price has influence on tourist demand. According to Saayman and Saayman (2008) who used travel cost as proxy of crude oil price to determined tourist demand but this study is extend to use variation of crude oil price to determine appropriate result to generate demands of tourist by local and foreign travelers.

In addition. Some other studies have explored the relationship between macroeconomic factors and tourism industry. For instance, (Meo, Chowdhury, Shaikh, Ali, \& Masood Sheikh, 2018) have examined the impact of change in oil prices, exchange rate for the demand in tourism industry of Pakistan. For this purpose, they have applied ARDL approach with the cointegration method. Findings of their study reveals the fact that there is a significant effect of $\mathrm{CO} 2$ emission on the value of tourism demand in Pakistan. While other factors like quality of institution have shown their long run association with the prices of oil, inflation, changes in exchange rate for tourism demand. In addition, some others like (Buckley, Gretzel, Scott, Weaver, \& Becken, 2015) explored the relationship between the facility of local infrastructure in the form of transportation on the value of tourism industry. He explained that increase in the oil prices have their significant and adverse influence on the tourism demand in local market. The study of (Katircioglu, Katircioglu, \& Altun, 2018) explained that changes in the oil price is associated to the economic growth and both demand and supply forces in the economy. They have explained that supply side is directed effected due to more production cost, while demand side is affected as well. It is also believed that tourism industry can also create the income inequality and can affect the Kuznets curve hypothesis (Alam \& Paramati, 2016).

Becken (2011) has explained the relationship between oil and global tourism industry. It is believed that oil price is linked to world economy and in similar way to the tourism too. To analyze this objective, author has explored the economy of New Zealand under the situation of dwindling of global oil. Study was based on the four different research phases. Their finding indicates the fact that significant association between tourism industry and oil price in the world economy exists. (Blomberg, Hess, \& Jackson, 2009) also consider the factor of oil price and its association with the tourism. (Gunter, 2018; Lechner et al, 2018; Habib \& Mucha Sr, 2018; Madhusudhanan, 2018) examines the conditional forecasting for the export of tourism and tourism export prices in the region of EU 15-member states under the title of global vector autoregression method. Time duration of the study was 2013 to 2017. Findings through GVAR explains that global tourist income is relative associated to the price ensurity. Practical implication of the study reveals that global market share is rising in competition. The detailed investigation and critical review of present literature shows that regional economic indicators are directly or indirectly affecting the tourism industry in different economies. However, the studies from the context of south Asian and ASEAN members are very limited. Notable work can be viewed in the studies of (Hall, 1992; Hall \& Page, 2012; Hitchcock, King, \& Parnwell, 2018; Richter, 1989; Wong, Mistilis, \& Dwyer, 2011; Moussa, 2018). The focus of these studies is based on the review of tourism sector through intergovernmental collaboration, super nationalist's alliance, economic impacts, economic development, and under the title of preconditions and framework for the policy development as well. In this regard, intergovernmental coordination is found to be very much significant and persistent. To the best of authors findings, this study is very first attempt to explore the idea of tourism revenue in targeted economies through regional economic indicators.

\section{Description of Variables}

Table 1 provides the description of variables through their operational abbreviation, operational definition and literature source. 
Table 1. Definition of Variables

\begin{tabular}{|c|c|c|c|}
\hline $\begin{array}{c}\text { Variable } \\
\text { Name }\end{array}$ & $\begin{array}{c}\text { Operational } \\
\text { Abbreviation }\end{array}$ & Operational Definition & Source of Literature \\
\hline $\begin{array}{c}\text { Tourism } \\
\text { Revenue }\end{array}$ & TOURISMREVENUE & $\begin{array}{c}\text { Indicates overall earnings } \\
\text { from tourism industry in a year }\end{array}$ & $\begin{array}{c}\text { (Archabald \& Naughton-Treves, 2001; } \\
\text { Sandbrook, 2010; Vijaya, 2010) }\end{array}$ \\
\hline Inflation & INFLATION & $\begin{array}{c}\text { Gradual increase in the prices of goods } \\
\text { and services in the country }\end{array}$ & $\begin{array}{c}\text { (Fama \& Schwert, 1977; } \\
\text { Gali \& Gertler, 1999) }\end{array}$ \\
\hline Oil Price & OILPRICE & Annual price of oil in the country & (Perron, 1989; Sadorsky, 1999) \\
\hline Exchange Rate & ER & $\begin{array}{c}\text { Annual effective exchange } \\
\text { rate per US dollar }\end{array}$ & $\begin{array}{c}\text { (De Grauwe \& Grimaldi, 2018; } \\
\text { Gabaix \& Maggiori, 2015) }\end{array}$ \\
\hline $\begin{array}{c}\text { Stock Market } \\
\text { Index }\end{array}$ & SMIND & $\begin{array}{c}\text { Covers the measurement of section } \\
\text { of stock, measured through selected } \\
\text { prices and weighted average. }\end{array}$ & $\begin{array}{c}\text { (Moghaddam, Moghaddam, \& Esfandyari, } \\
\text { 2016; Patel, Shah, Thakkar, \& Kotecha, 2015) }\end{array}$ \\
\hline $\begin{array}{c}\text { Industrial } \\
\text { Growth }\end{array}$ & IGR & $\begin{array}{c}\text { Annual growth rate in overall } \\
\text { industry of a country }\end{array}$ & (Barnett, 2016; Oakey \& Rothwell, 2018) \\
\hline
\end{tabular}

\section{Research Methodology}

This study has used secondary data from five economies in ASEAN region. For this purpose, data is collected over last five years for macroeconomic indicators are tourism revenue in selected countries. After the collection of data regression analysis approach is applied under separate econometric equations, covering the causal relationship between the independent and dependent variables of the study. For better understanding of applied methodology, following equations will help the reader to understand the predicted relationship between variables. Each equation presents separate regions, covering both IVs and DVs, while coefficients are abbreviated under the title of $\mathrm{B}_{0}, \mathrm{~B}_{1}, \mathrm{~B}_{2}$ up to $\mathrm{B}_{\mathrm{n}}$. In addition, error terms are covered under the title of $€$. Each equation indicates sperate region for the tourism receipt and its core determinants from their economy. Equation 1 is for the economy of Malaysia, equation 2 for the Indonesia, equation three for Thailand, equation four for Singapore, and equation five considers for the economy of Brunei. Relationship under these equations is tested through STATA-14 version, while adjusting the standard errors in the coefficients through robust command.

Tourism Receipt $($ Malaysia $)=B 0+b 1($ Inflation $)+b 2($ oil prices $)+$ b3 (exchange rate: $E R)+b 4($ stock market index: $S M I N D)+$ $b 5($ industrial growth:IGR $)+b 6(G D P)+€$

\section{Equation 1}

Tourism Receipt $($ Indonesia $)=B 0+b 1($ Inflation $)+b 2($ oil prices $)+$ $b 3($ exchange rate: $E R)+b 4($ stock market index:SMIND) + $b 5($ industrial growth:IGR $)+b 6(G D P)+€$

\section{Equation 2}

Tourism Receipt $($ Thailand $)=B 0+b 1($ Inflation $)+b 2($ oil prices $)+$ $b 3($ exchange rate: $E R)+b 4($ stock market index: $S M I N D)+$ $b 5($ industrial growth: IGR $)+b 6(G D P)+€$

\section{Equation 3}

Tourism Receipt $($ Singapore $)=B 0+b 1($ Inflation $)+b 2($ oil prices $)+$ $b 3($ exchange rate: $E R)+b 4($ stock market index: SMIND) + $b 5($ industrial growth:IGR $)+b 6(G D P)+€$

\section{Equation 4}




\section{Tourism Receipt $($ Brunei $)=B 0+b 1($ Inflation $)+b 2$ (oil prices $)+$ b3 (exchange rate: $E R)+b 4($ stock market index: SMIND) + $b 5($ industrial growth:IGR) $+b 6(G D P)+€$}

\section{Equation 5}

\section{Results and Discussion}

For the effect of macroeconomic indicators on tourism revenue in Malaysia, Table 2 provides statistical findings. For regional economic factors, inflation, price of oil, exchange rate, stock market index, industrial growth rate and gross domestic product are added in the model. Through inflation, effect on tourism revenue is Malaysia, it has significant negative influence. It means that more increase in the prices of goods and services are local level is leading towards adversely affecting the revenue from the tourism industry. This effect is significant at 1 percent level of significance. While effect of oil prices in the local market has indicates its negative but insignificant impact on tourism revenue of Malaysia. While exchange rate is found to be significant determinant of tourism revenue, showing the coefficient of -.058 and standard error of .164 respectively. Through stock market index, industrial growth both indicators have shown their insignificant association with the level of tourism revenue. But the effect through GDP is found to be positively significant with the coefficient of .227, standard error of .042 and t-value of 10.31 as well. F-test shows significant of the model while R-square indicates an explanatory power of .463 for the region of Malaysia.

Table 2. Tourism revenue and macroeconomic determinants: Malaysia

\begin{tabular}{|c|c|c|c|c|c|}
\hline TOURISMREVENUE & Coef. & St.Err & $\mathrm{t}$-value & p-value & Sig. \\
\hline INFLATION & -0.393 & 0.038 & -1034 & 0.000 & $* * *$ \\
\hline OILPRICE & -0.070 & 0.047 & -1.49 & 0.165 & \\
\hline ER & -0.286 & 0.164 & -1.75 & 0.109 & $*$ \\
\hline SMIND & -0.058 & 0.323 & -0.18 & 0.860 & \\
\hline IGR & -0.142 & 0.122 & -1.17 & 0.267 & \\
\hline GDP & 0.227 & 0.042 & 10.31 & 0.000 & $* * *$ \\
\hline CONS & -1.644 & 1.236 & -1.33 & 0.210 & \\
\hline \multicolumn{2}{|l|}{ Mean dependent var } & 0.134 & SD dependent var & \multicolumn{2}{|c|}{0.288} \\
\hline R-squared & \multicolumn{2}{|c|}{0.463} & Number of obs & \multicolumn{2}{|c|}{18.000} \\
\hline F-test & \multirow{2}{*}{\multicolumn{2}{|c|}{$\begin{array}{l}4.581 \\
8.082\end{array}$}} & Prob $>F$ & \multicolumn{2}{|c|}{0.021} \\
\hline Akaike crit. (AIC) & & & Bayesian crit. (BIC) & \multicolumn{2}{|c|}{14.314} \\
\hline
\end{tabular}

Table 3 indicates regression findings for tourism revenue and macroeconomic determinants in the region of Indonesia. Through oil price, effect on tourism revenue is found to be significant and negative at 1 percent chance of error. It means that more oil prices in Indonesia has their adverse influence on revenue from tourism. For exchange rate, effect on tourism revenue is found to be positively significant at 1 percent chance of error. While stock market index also shows its no influence on tourism revenue. Through GDP, coefficient of .1024 explains that increasing gross domestic products have their positive influence on tourism revenue in Indonesia. The determination of tourism revenue through macroeconomic variables on tourism industry is significant as Ftest has a score of 94.648, with p-value of .000. While explained variation in Dependent variable is .812 shows a good variation in tourism revenue by targeted macroeconomic indicators.

Table 4 specifies regression findings for tourism revenue and macroeconomic determinants in the Thailand. It 
is observed that effect of oil price on tourism revenue is found to be significant and positive at 5 percent chance of error. It means that more oil prices in Thailand is showing their direct impact on revenue from tourism. For exchange rate, effect on tourism revenue is found to be negative but insignificant at 1,5 and 10 percent chance of error. While stock market index also shows its positive and significant influence on tourism revenue with the coefficient of .585. Through GDP, coefficient of .029 explains that increasing gross domestic products have their positive but insignificant influence on tourism revenue in Thailand. In addition, F-test has a score of 9.233, with p-value of .000 , significant at 1 percent. While explained variation in Dependent variable is .787 due to all macroeconomic regional indicators.

Table 3. Tourism revenue and macroeconomic determinants: Indonesia

\begin{tabular}{|c|c|c|c|c|c|}
\hline TOURISMREVENUE & Coef. & St.Err & t-value & $\mathrm{p}$-value & Sig. \\
\hline INFLATION & 0.042 & 0.040 & 1.05 & 0.319 & \\
\hline OILPRICE & -0.040 & 0.019 & -2.08 & 0.067 & $*$ \\
\hline ER & 4.510 & 0.311 & 14.51 & 0.000 & $* * *$ \\
\hline SMIND & -0.077 & 0.044 & -1.77 & 0.111 & \\
\hline IGR & 0.007 & 0.002 & 3.57 & 0.006 & $* * *$ \\
\hline GDP & .1024 & .0142 & 7.21 & 0.000 & $* * *$ \\
\hline _cons & 0.333 & 0.159 & 2.09 & 0.066 & $*$ \\
\hline \multicolumn{2}{|l|}{ Mean dependent var } & 0.133 & SD dependent var & \multicolumn{2}{|c|}{0.196} \\
\hline R-squared & \multicolumn{2}{|c|}{0.812} & Number of obs & \multicolumn{2}{|c|}{16.000} \\
\hline F-test & \multicolumn{2}{|c|}{94.648} & Prob $>$ F & \multicolumn{2}{|c|}{0.000} \\
\hline Akaike crit. (AIC) & -55.139 & \multicolumn{2}{|c|}{ Bayesian crit. (BIC) } & \multicolumn{2}{|c|}{-50.891} \\
\hline
\end{tabular}

$$
* * * \mathrm{p}<0.01, * * \mathrm{p}<0.05, * \mathrm{p}<0.1
$$

Table 4. Tourism revenue and macroeconomic determinants: Thailand

\begin{tabular}{|c|c|c|c|c|c|}
\hline TOURISMREVENUE & Coef. & St.Err & t-value & $\mathrm{p}$-value & Sig. \\
\hline INFLATION & -0.028 & 0.023 & -1.22 & 0.242 & \\
\hline OILPRICE & 0.060 & 0.024 & 2.53 & 0.023 & $* *$ \\
\hline ER & -0.027 & 0.027 & -1.01 & 0.330 & \\
\hline SMIND & 0.585 & 0.173 & 3.38 & 0.004 & $* * *$ \\
\hline IGR & -0.007 & 0.003 & -2.18 & 0.045 & $* *$ \\
\hline GDP & 0.029 & 0.018 & 1.65 & 0.120 & \\
\hline _cons & -0.182 & 0.138 & -1.31 & 0.208 & \\
\hline \multicolumn{2}{|l|}{ Mean dependent var } & 0.062 & SD dependent var & \multicolumn{2}{|c|}{0.067} \\
\hline R-squared & 0.787 & \multicolumn{2}{|c|}{ Number of obs } & \multicolumn{2}{|c|}{18.000} \\
\hline F-test & 9.233 & \multicolumn{2}{|c|}{ Prob $>$ F } & \multicolumn{2}{|c|}{0.000} \\
\hline Akaike crit. (AIC) & -77.737 & \multicolumn{2}{|c|}{ Bayesian crit. (BIC) } & \multicolumn{2}{|c|}{-70.100} \\
\hline
\end{tabular}

$$
* * * \mathrm{p}<0.01, * * \mathrm{p}<0.05, * \mathrm{p}<0.1
$$

Table 5 shows the effect of macroeconomic variables on tourism revenue in Singapore. It is found that inflation, oil price and exchange rates has no direct influence on the receipt from tourism. While stock market index, and industrial growth has shown their positive and significant impact with the coefficients of 1.458 and .081 . It means that more receipt of tourism industry is possible with the factors like stock market index and overall industrial growth in the economy. While effect through GDP is found to be insignificant on tourism revenue in the region of Singapore. 
Table 5. Tourism revenue and macroeconomic determinants: Singapore

\begin{tabular}{|c|c|c|c|c|c|}
\hline TOURISMREVENUE & Coef. & St.Err & t-value & p-value & Sig. \\
\hline INFLATION & -0.007 & 0.013 & -0.53 & 0.603 & \\
\hline OILPRICE & 0.003 & 0.010 & 0.35 & 0.730 & \\
\hline ER & -0.006 & 0.009 & -0.67 & 0.512 & \\
\hline SMIND & 1.458 & 0.067 & 21.80 & 0.000 & $* * *$ \\
\hline IGR & 0.081 & 0.004 & 2.13 & 0.051 & $*$ \\
\hline GDP & -0.006 & 0.011 & -0.50 & 0.623 & \\
\hline _cons & 0.019 & 0.093 & 0.21 & 0.839 & \\
\hline \multicolumn{2}{|l|}{ Mean dependent var } & 0.040 & SD dependent var & \multicolumn{2}{|c|}{0.113} \\
\hline R-squared & \multicolumn{2}{|c|}{0.975} & Number of obs & \multicolumn{2}{|c|}{18.000} \\
\hline F-test & \multicolumn{2}{|c|}{96.340} & Prob $>$ F & \multicolumn{2}{|c|}{0.000} \\
\hline Akaike crit. (AIC) & -101.266 & \multicolumn{2}{|c|}{ Bayesian crit. (BIC) } & \multicolumn{2}{|c|}{-93.629} \\
\hline
\end{tabular}

$$
* * * \mathrm{p}<0.01, * * \mathrm{p}<0.05, * \mathrm{p}<0.1
$$

For tourism revenue in the region of Brunei, Table 6 reflects the effect of macroeconomic indicators. It is found that inflation and oil price found to be insignificant determinants of tourism revenue. While exchange rate has shown a negative and significant effect of -.012 in Brunei. It means that more volatility in exchange rate causing to an opposite effect on tourism income. While through stock market index effect is significantly positive with the coefficient of .154 and standard error of .018 respectively. Additionally, both industrial growth and GDP are found to be significant affecting the tourism receipt.

Table 6. Tourism revenue and macroeconomic determinants: Brunei

\begin{tabular}{|c|c|c|c|c|c|}
\hline TOURISMREVENUE & Coef. & St.Err & $\mathrm{t}$-value & p-value & Sig. \\
\hline INFLATION & 0.012 & 0.017 & 0.71 & 0.486 & \\
\hline OILPRICE & 0.001 & 0.002 & 0.55 & 0.591 & \\
\hline ER & -0.012 & 0.002 & 6.024 & 0.000 & $* * *$ \\
\hline SMIND & 0.154 & 0.018 & 8.58 & 0.000 & $* * *$ \\
\hline IGR & 0.011 & 0.008 & 1.46 & 0.163 & \\
\hline GDP & 0.033 & 0.017 & 2.00 & 0.063 & $*$ \\
\hline _cons & -0.279 & 0.147 & -1.90 & 0.076 & $*$ \\
\hline \multicolumn{2}{|l|}{ Mean dependent var } & \multicolumn{2}{|c|}{ SD dependent var } & \multicolumn{2}{|c|}{0.071} \\
\hline \multicolumn{2}{|l|}{ R-squared } & \multicolumn{2}{|c|}{ Number of obs } & \multicolumn{2}{|c|}{18.000} \\
\hline \multicolumn{2}{|l|}{ F-test } & \multicolumn{2}{|c|}{ Prob $>F$} & \multicolumn{2}{|c|}{0.000} \\
\hline Akaike crit. (AIC) & & \multicolumn{2}{|c|}{ Bayesian crit. (BIC) } & \multicolumn{2}{|c|}{-88.615} \\
\hline
\end{tabular}

$$
* * * \mathrm{p}<0.01, * * \mathrm{p}<0.05, * \mathrm{p}<0.1
$$

\section{Conclusions and Future Directions}

This study has examined the effect of macroeconomic factors on tourism revenue in five ASEAN countries. For this purpose, study has conducted OLS regression analysis technique for all five states. It is observed that in the region of Malaysia, regional economic indicators like Inflation, exchange rate changes, and gross domestic product have their significant impact on the income from tourism industry over last 18 years of the study. In case of Indonesia, key indicators from the macroeconomic environment for tourism revenue are found to be 
oil prices, exchange rate, industrial growth and gross domestic products. Regression findings for the region of Thailand has shown that key factors to affect tourism income are oil price, stock market index, and industrial growth with good explanatory power of the model. Empirical findings for Singapore suggested that there is a significant need to focus on the factors like stock market index, and industrial growth having their direct influence for increasing value of tourism revenue in the country. While in case of Brunei, it is found that key determinants are exchange rate, industrial growth and gross domestic product along with stock market index. Bases on these findings, this study is highly recommended to the reserachers, academics and policy makers at regional level who are analyzing the relationship between tourism industry and its key determinants at macrolevel. Study findings can be very much beneficial for present decision-making regarding growth in tourism industry in ASEAN region. Additionally, students in the field of economics and business management can review the causal relationship between the key variables of this study. However, this study has several limitations. At first study is just focusing on the macroeconomic factors, while ignoring micro indicators. At second, sample period is less than 20 years which assumes to be not very good for the long run analysis. At third, cross sectional and comparative analysis of selected states is missing in this study. Future work should address these limitations for better findings and more appropriate managerial implications.

\section{References}

Alam, M. S., \& Paramati, S. R. (2016). The impact of tourism on income inequality in developing economies: Does Kuznets curve hypothesis exist? Annals of Tourism Research, 61, 111-126. Available at: https://doi.org/10.1016/j.annals.2016.09.008

Algieri, B. (2006). An econometric estimation of the demand for tourism: the case of Russia. Tourism Economics, 12(1), 5-20. Available at: https://doi.org/10.5367/000000006776387114

Archabald, K., \& Naughton-Treves, L. (2001). Tourism revenue-sharing around national parks in Western Uganda: early efforts to identify and reward local communities. Environmental conservation, 28(2), 135-149. Available at: https://doi.org/10.1017/s0376892901000145

ASEAN Tourism Agreement. (2015). ASEAN Tourism Agreement,. from https://asean.org/?static_post=asean-tourism-agreement

Barnett, V. (2016). Kondratiev and the dynamics of economic development: long cycles and industrial growth in historical context: Springer, p. 356.

Becken, S. (2011). Oil, the global economy and tourism. Tourism Review, 66(3), 65-72. Available at: https://doi.org/10.1108/ 16605371111175339

Blomberg, B., Hess, G., \& Jackson, J. H. (2009). Terrorism and the Returns to Oil. Economics \& Politics, 21(3), 409-432. Available at: https://doi.org/10.1111/j.1468-0343.2009.00357.x

Box, G. E., \& Cox, D. R. (1964). An analysis of transformations. Journal of the Royal Statistical Society: Series B (Methodological), 26(2), 211-243.

Buckley, R., Gretzel, U., Scott, D., Weaver, D., \& Becken, S. (2015). Tourism megatrends. Tourism Recreation Research, 40(1), 59-70. Available at: https://doi.org/10.1080/02508281.2015.1005942

Chkalova, O., Efremova, M., Lezhnin, V., Polukhina, A., Sheresheva, M. (2019). Innovative mechanism for local tourism system management: a case study. Entrepreneurship and Sustainability Issues, 6(4), 2052-2067. http://doi.org/10.9770/jesi.2019.6.4(35)

Chen, M.-H. (2007a). Interactions between business conditions and financial performance of tourism firms: Evidence from China and Taiwan. Tourism Management, 28(1), 188-203. Available at: https://doi.org/10.1016/j.tourman.2005.11.012

Chen, M.-H. (2007b). Macro and non-macro explanatory factors of Chinese hotel stock returns. International Journal of Hospitality Management, 26(4), 991-1004. Available at: https://doi.org/10.1016/j.ijhm.2006.04.002

Croes, R. R., \& Vanegas Sr, M. (2005). An econometric study of tourist arrivals in Aruba and its implications. Tourism Management, 26(6), 879-890. Available at: https://doi.org/10.1016/j.tourman.2004.04.007

De Grauwe, P., \& Grimaldi, M. (2018). The exchange rate in a behavioral finance framework: Princeton University Press.

Dritsakis, N. (2004). Cointegration analysis of German and British tourism demand for Greece. Tourism Management, 25(1), 111-119. Available at: https://doi.org/10.1016/s0261-5177(03)00061-x 
Fama, E. F., \& Schwert, G. W. (1977). Asset returns and inflation. Journal of financial economics, 5(2), 115-146. Available at: https://doi. org/10.1016/0304-405x(77)90014-9

Gabaix, X., \& Maggiori, M. (2015). International liquidity and exchange rate dynamics. The Quarterly Journal of Economics, 130(3), 1369-1420. Available at: https://doi.org/10.1093/qje/qjv016

Gal1, J., \& Gertler, M. (1999). Inflation dynamics: A structural econometric analysis. Journal of monetary Economics, 44(2), $195-222$. Available at: https://doi.org/10.1016/s0304-3932(99)00023-9

Gunter, U. (2018). Conditional forecasts of tourism exports and tourism export prices of the EU-15 within a global vector autoregression framework. Journal of Tourism Futures, 4(2), 121-138. Available at: https://doi.org/10.1108/jtf-01-2017-0001

Hall, C. M., \& Page, S. (2012). Tourism in south and Southeast Asia: Routledge.

Hall, C. M. (1992). Sex tourism in South-east Asia. Sex tourism in South-east Asia., 64-74.

Hassan, H. S., \& Alanazi, T. M. (2018). Roles of Islamic Business Ethics in the Formation of Internal Organisational Culture: A Qualitative Approach of Muslims' SMEs in the UK. International Journal of Economics, Business and Management Studies, 5(1), 16-30.

Hiemstra, S., \& Wong, K. K. (2002). Factors affecting demand for tourism in Hong Kong. Journal of Travel \& Tourism Marketing, 13(12), 41-60. Available at: https://doi.org/10.1300/j073v13n01_04

Hitchcock, M., King, V. T., \& Parnwell, M. J. (2018). Tourism in south-east Asia (Vol. 32): Routledge.

Hossain, M. A., Hossain, M. S., \& Jahan, N. (2018). Predicting Continuance Usage Intention of Mobile Payment: An Experimental Study of Bangladeshi Customers. Asian Economic and Financial Review, 8(4), 487-498.

Hussain, H.I., Shamsudin, M.F., Anwar, N.A.M., Salem. M.A. \& Jabarullah, N.H. (2018). The Impact of Shari'ah Compliance on the Adjustment to Target Debt Maturity of Malaysian Firms, European Research Studies Journal, 21 (2), 48 - 61.

Islam, S., Nahar, T. N., Begum, J., Khatun, M., \& Hossain, M. I. (2018). Marketing and Financial Analysis of Milk Production-A Value Chain Perspective. Asian Development Policy Review, 6(1), 32-40.

Jang, S. S., Bai, B., Hong, G.-S., \& O’Leary, J. T. (2004). Understanding travel expenditure patterns: a study of Japanese pleasure travelers to the United States by income level. Tourism Management, 25(3), 331-341. Available at: https://doi.org/10.1016/s0261-5177(03)00141-9

Katircioglu, S., Katircioglu, S., \& Altun, O. (2018). The moderating role of oil price changes in the effects of service trade and tourism on growth: the case of Turkey. Environmental Science and Pollution Research, 25(35), 35266-35275. Available at: https://doi.org/10.1007/ s11356-018-3448-2

Kabir, M. A., Abba, M., \& Abubakar, A. (2018). An Empirical Study on the Use Intention of Electronic Cash Collection System in Nigerian Federal Hospitals. International Journal of Emerging Trends in Social Sciences, 3(2), 65-73.

Keho, Y. (2017). The Exports and Economic Growth Nexus in Cote D'ivoire: Evidence from a Multivariate Time Series Analysis. Asian Journal of Economic Modelling, 5(2), 135-146.

Khan, I. (2018). The Impact of Land Use on Spatial Variations of Begging in District Lahore_Pakistan. International Journal of Geography and Geology, 7(2), 27-34.

Lim, C., Min, J. C., \& McAleer, M. (2008). Modelling income effects on long and short haul international travel from Japan. Tourism Management, 29(6), 1099-1109. Available at: https://doi.org/10.1016/j.tourman.2008.02.012

Lari, L. R. A., NYangweso, P. M., \& Rono, L. J. (2017). Determinants of Technical Inefficiency of Saccos in Kenya: A Net Operating Cash Flows Output Slack Analysis. Asian Journal of Economics and Empirical Research, 4(2), 49-60.

Lechner, G., Craß, N., Kraleva, D., Scharer, V., Iwański, J., \& Giraud, S. (2018). Financial Education for Child and Youth Care Practitioners. Journal of Accounting, Business and Finance Research, 2(2), 55-63.

Meo, M. S., Chowdhury, M. A. F., Shaikh, G. M., Ali, M., \& Masood Sheikh, S. (2018). Asymmetric impact of oil prices, exchange rate, and inflation on tourism demand in Pakistan: new evidence from nonlinear ARDL. Asia Pacific Journal of Tourism Research, 23(4), 408422. Available at: https://doi.org/10.1080/10941665.2018.1445652

Madhusudhanan, S. (2018). Gender Responsive Budgeting: A Lesson Learned and Way Forward. International Journal of Applied Economics, Finance and Accounting, 2(1), 27-29.

Mahrinasari, M., Haseeb, M., Ammar, J., Meiryani, M. (2019). Does Trade Liberalization a Hazard to Sustainable Environment? Fresh 
Insight from ASEAN Countries. Polish Journal of Management Studies, 19 (1), 200-210.

Moussa, A. (2018). Does Agricultural Sector Contribute to the Economic Growth in Case of Republic of Benin?. Journal of Social Economics Research, 5(2), 85-93.

Moghaddam, A. H., Moghaddam, M. H., \& Esfandyari, M. (2016). Stock market index prediction using artificial neural network. Journal of Economics, Finance and Administrative Science, 21(41), 89-93. Available at: https://doi.org/10.1016/j.jefas.2016.07.002

Oakey, R., \& Rothwell, R. (2018). High technology small firms and regional industrial growth Technological change, industrial restructuring and regional development (pp. 258-282): Routledge.

Patel, J., Shah, S., Thakkar, P., \& Kotecha, K. (2015). Predicting stock market index using fusion of machine learning techniques. Expert Systems with Applications, 42(4), 2162-2172. Available at: https://doi.org/10.1016/j.eswa.2014.10.031

Perron, P. (1989). The great crash, the oil price shock, and the unit root hypothesis. Econometrica: Journal of the Econometric Society, 1361-1401. Available at: https://doi.org/10.2307/1913712

Richter, L. K. (1989). The politics of tourism in Asia: University of Hawaii Press.

Saayman, A., \& Saayman, M. (2008). Determinants of inbound tourism to South Africa. Tourism Economics, 14(1), 81-96. Available at: https://doi.org/10.5367/000000008783554893

Sadorsky, P. (1999). Oil price shocks and stock market activity. Energy economics, 21(5), 449-469. Available at: https://doi.org/10.1016/ s0140-9883(99)00020-1

Sandbrook, C. G. (2010). Putting leakage in its place: The significance of retained tourism revenue in the local context in rural Uganda. Journal of International Development: The Journal of the Development Studies Association, 22(1), 124-136. Available at: https://doi. org/10.1002/jid.1507

Secretariat, A. (2015). ASEAN Tourism Strategic Plan 2016-2025 (pp. 1-90). ASEAN Secretariat.

Secretariat, A. (2016). Asean secretariat.

Seo, J. H., Park, S. Y., \& Yu, L. (2009). The analysis of the relationships of Korean outbound tourism demand: Jeju Island and three international destinations. Tourism Management, 30(4), 530-543. Available at: https://doi.org/10.1016/j.tourman.2008.10.013

Shevyakova, A., Munsh, E., Arystan, M. (2019). Information support for the development of tourism for the diversification of the economy of Kazakhstan. Insights into Regional Development, 1(2), 138-154. https://doi.org/10.9770/ird.2019.1.2(5)

Vijaya, R. M. (2010). Medical tourism: revenue generation or international transfer of healthcare problems? Journal of Economic Issues, 44(1), 53-70. Available at: https://doi.org/10.2753/jei0021-3624440103

Wang, Y.-S. (2009). The impact of crisis events and macroeconomic activity on Taiwan's international inbound tourism demand. Tourism Management, 30(1), 75-82. Available at: https://doi.org/10.1016/j.tourman.2008.04.010

Wattanakuljarus, A., \& Coxhead, I. (2008). Is tourism-based development good for the poor?: A general equilibrium analysis for Thailand. Journal of Policy Modeling, 30(6), 929-955.

Wong, E. P., Mistilis, N., \& Dwyer, L. (2011). A framework for analyzing intergovernmental collaboration-The case of ASEAN tourism. Tourism Management, 32(2), 367-376. Available at: https://doi.org/10.1016/j.tourman.2010.03.006

World Tourism Organization. (2019). World Tourism Organization.

World travel and tourism council. (2017). World travel and tourism council from https://www.wttc.org// 
Dr. Muhammad HASEEB is currently serving as a senior lecturer in Taylors Business School (TBS), Taylors University Malaysia. He have 15 years working expreince in industry and academia. He is recipient of several best papers award, national and international scholarships and research grants. He is editor, reviewer and author of several Scopus and ISI indexed journals. His research interest are Environemtnal and natural resurce economics, energy economics, International trade and sustainable development.

ORCID ID: org/0000-0002-0307-6751

Associate Professor Dr. GholamReza ZANDI is currently Head of Research and Innovation Section at Business School, Universiti Kuala Lumpur, Malaysia. He earned his Ph.D. degree from Universiti Sains Malaysia (USM) in 2007 specializing in Financial Accounting and Corporate Governance. He also carries Professional Qualification as Certified Practicing Accountant (CPA) from Australia. His research articles have been published in many national and international reputed journals. He has been awarded a few Medals from International Research, Invention and Innovation for his research studies. Dr. GholamReza has more than 20 years' experience of teaching to both undergraduate and postgraduate level and received a few International and national research grants. His research interests are in the areas of Corporate Governance, Financial Reporting \& Disclosure, Accounting Education Behavioral and Islamic Finance \& Banking.

Nizam Mohammad ANDRIANTO is lecturer of Management Departement of Economic Faculty Pakuan University placed at Bogor, Indonesia and Director of Business Incubator of Economics Faculty handle companies that need management assistance. He is also chairman of the employee cooperative of Pakuan University. Research interests: tourism industry; entrepreneurship; small and medium enterprise; consumer behavior.

Thitinan Chankoson is an Assistant Professor of Business Administration at the Faculty of Business Administration for Society, Srinakharinwirot University, Thailand and an Academic and Research Counselor for Thai Studies Center of Yulin Normal University, China. He holds a Doctor of Science in International Service Business Management from North Eastern University, Thailand. His research interests are service business management, aviation management, international business management, supply chain management, tourism and hospitality industry.

ORCID ID: orcid.org/0000-0003-1855-678X

This work is licensed under the Creative Commons Attribution International License (CC BY). http://creativecommons.org/licenses/by/4.0/ 